\title{
Nomenclatural notes and lectotypification in the monotypic genus Getonia (Combretaceae)
}

\author{
S.C. Patil \\ Botanical Survey of India, Northern Regional Centre, 192 Kaulagarh Road, Dehradun, Uttarakhand - 248 195, India. \\ E-mail: sameerpatil.c@gmail.com
}

\begin{abstract}
Nomenclature confusion between the names Getonia and Calycopteris is discussed and clarified. J.P. Rottler's specimen at Kew is designated here as the lectotype of the name Getonia floribunda Roxb.
\end{abstract}

Keywords: Calycopteris, Getonia floribunda, India, Nomenclature.

\section{Introduction}

The name Getonia Roxb. is currently used for the monotypic genus of Combretaceae distributed in the Indo-Malayan region (Mabberly, 2018). It is a common undergrowth of low-lying tropical evergreen forests. The plant is well known among local people, medicinal practitioners and ethnobotanists for its medicinal uses (Dey et al., 2007; Pavithra et al., 2013; Asma \& Afidam, 2014; Glory et al., 2016; Vantamuri et al., 2017). Calycopteris Lam. is another name used for this genus which is invalid (IPNI, 2020). The name Calycopteris first appeared in 1793 by Lamarck whereas the name Getonia appeared firstly through Roxburgh in 1798. Considering the principle of priority Art. 11.3 (Turland et al., 2018), Calycopteris is to be the preferred name over Getonia. While preparing notes for the Flora of Pushpagiri Wildlife Sanctuary, Karnataka, a study of historical specimens and literature revealed that the nomenclature of both names was incorrectly understood and needs to be elucidated.

Received: 11.03.2020; Revised \& Accepted: 11.06 .2020

Published Online: 30.09 .2020

\section{Nomenclature}

Lamarck (1793) published "Calycopteris", in tome 1, volume 2, part 2, fig. 357, which was published on 11 February 1793 (Stafleu \& Cowan, 1979). The name appeared in the plate with an analysis, but not in the printed pages that would have been published at the same time. According to Art. 38.7, any name is validly published prior to 1 January 1908 , if accompanied by illustration with analysis and no description; but the article is restricted only for a monotypic genus (i.e., genus name + a single species name), and not for only genus name. Since, the name Calycopteris was published without any species it does not satisfy the Art. 38.7, thus is invalidly published.

The name appeared with a proper diagnosis in tome 2 , volume 5, part 2, page 461, which was published later, on 31 October 1819. Along with it, the name Calycopteris floribunda also appeared in the same book on page 485 , and so was also published on the same day in 1819, thus making it a case of valid publication to be considered under Art. 38.5. Roxburgh (1798), perhaps unaware of Lamarck's publication described the same taxon as "Getonia" providing a detailed description of the only species within the genus i.e. Getonia floribunda Roxb. making it a valid publication according to the Code. However, before Lamarck (1819), Poiret (1811) validated Calycopteris by transferring Roxburgh's G. floribunda to the genus, thus providing a reference to it. Hence, based on the above discussion, the name Calycopteris was introduced invalidly in a plate in 1793 , but the analysis and 
description was published in 1819. The validation would date to 1819 , except that it was validated by Poiret in 1811 and that name is thus illegitimate and superfluous because Getonia had been validly published earlier in 1798.

The name Calycopteris floribunda was accepted until late 2000 by many authors (Clarke, 1878; Birdwood, 1887; Cooke, 1903; Talbot, 1911; Gamble, 1919; Craib, 1931; Exell, 1954; Sharma et al., 1984; Diwakar, 2001; Murthy \& Nair, 2018). It was Mabberly (2008) who first pointed out that Getonia has priority over Calycopteris. Nevertheless, many online databases use the name Getonia over Calycopteris. This is now been followed by some recent authors (Punekar \& Lakshminarasimhan, 2011; Datar \& Lakshminarasimhan, 2013; Paul et al., 2015; Mabberly, 2018).

Getonia floribunda Roxb., Pl. Coromandel 1(4): 61, t. 87. 1798. Calycopteris floribunda (Roxb.) Lam. ex Poir., Encycl. Suppl. 2: 41. 1811. Lectotype (designated here): s.loc., s.d., J.P. Rottler s.n. (K [K000786130 digital image!]).

Fig. 1

Getonia nitida Roth, Nov. Sp. Pl. 217. 1821 (type destroyed and no other original material exists).

Getonia nutans Roxb. ex DC., Prodr. 3: 15. 1828. Calycopteris nutans (Roxb.) Kurz J. Asiat. Soc. Bengal Pt. 2, Nat. Hist. 46: 59. 1877. Lectotype (designated by Gangopadhyay \& Chakrabarty, 1997): Roxburgh Icon. No. 2495 (2492) (CAL!).

\section{Typification}

Roxburgh (1798) while publishing Getonia floribunda did not cite any specimen in the protologue. The author consulted BM, BR, E, G, LIV where the majority of Roxburgh's specimens are reportedly located. However, the search proved to be unfruitful for tracing any original material connected with Roxburgh's annotations. However, a specimen in Kew (Herbarium Rottlerianum) with barcode K000786130 (Fig. 1) shows an annotation "Getonia floribunda Roxb. P1. Coromandel. Decandria. Roxburgh. Plant. Coromandel. 1, 87." which matches with Roxburgh's handwriting. J.P.
Rottler (1749-1836) a French missionary in Tranquebar, had correspondence and exchange of material with Roxburgh (Matthew, 1993). His materials now referred to as 'Herbarium Rottlerianum' were sent to King's College London by Sir H. Cleghorn and later transferred to RBG, Kew (Foulkes, 1861). The note mentioned above clearly indicates that Roxburgh was referring to his protologue [Roxburgh (1: 61, t. 87. 1798)]. It may be considered as the original material for the basis of the species description.

Gangopadhyay and Chakrabarty (1997) treated Getonia floribunda Roxb. as a synonym of Calycopteris floribunda Lam.. They cited the type as "Type: Roxburgh, Pl. Corom.: t. 87 \& Icon. 140 (CAL)". According to Dr. John McNeill (pers. comm., 2020) the plate t. 87 in Roxburgh's Plants

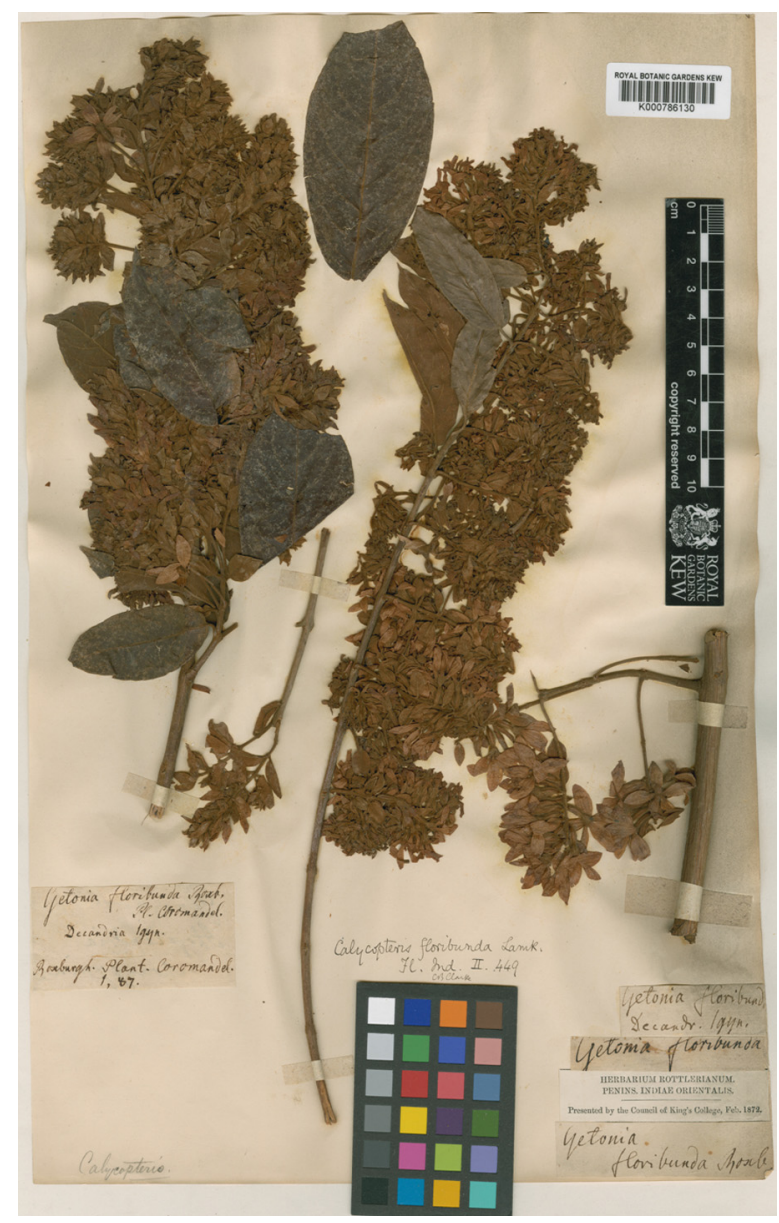

Fig. 1. Lectotype of Getonia floribunda (K000786130). (C) The Board of Trustees for the Royal Botanic Gardens, Kew. Reproduced with permission. 
of the Coast of Coromandel is, although derived from the drawings numbered 140 at $\mathrm{K}$ and CAL, a separate element so far as typification is concerned. Therefore, the 'type' citation by Gangopadhyay and Chakrabarty (1997) cannot be accepted as an inadvertent lectotypification (see Art. 7.11; Turland et al., 2018). If they had cited one of the two drawings then it would have been an effective lectotypification being before 2000 according to Art. 7.11 (Turland et al., 2018). Thus, in the context of the original material referred and annotated by Roxburgh found here to exist, it is hereby designated as the lectotype following Art. 9.19 (Turland et al., 2018).

\section{Acknowledgements}

I am thankful to Director, Botanical Survey of India, Kolkata for facilities and encouragement. I am also thankful to Dr. Kanchi Gandhi, Harvard, USA and to Dr. John McNeill, Royal Botanic Garden, Edinburgh for their valuable comments on improving the manuscript. Thanks are also due to curators of K, BM, BR, E, G and LIV for providing herbarium image access.

\section{Literature Cited}

ASMA V.M. \& K. AFIDAM 2014. Documentation of medicinal plants of selected sacred groves of Trichur district. International Journal of Current Research 6(3): 5657-5663.

BIRDWOOD H.M. 1887. A catalogue of the flora of Mahabaleshwar and Matheran. Journal of Bombay Natural History Society 2: 107-132.

CLARKE C.B. 1878. Combretaceae. In: HOOKER J.D. (ed.), Flora of British India. Volume 2. L. Reeve \& Co., London. p. 792.

COOKE T. 1903. Flora of Presidency of Bombay. Volume 1. Taylor \& Francis, London.

CRAIB W.G. 1931. Florae Siamensis enumeration: a list of the plants known from Siam. Volume 1. The Bangkok times press, Bangkok.

DATAR M.N. \& P. LAKSHMINARASIMHAN 2013. Flora of Bhagwan Mahavir (Molem) National Park and adjoining Goa. Botanical Survey of India, Kolkata.

DEYS.K.,SHOEBM., ROBT.,NAHARN.,MOSIHUZZAMAN M. \& N. SULTANA 2007. Biological and chemical studies on Calycopteris floribunda leaves. Dhaka University Journal of Pharmaceutical Science 4(2): 103-106. https:// doi.org/10.3329/dujps.v4i2.210

DIWAKAR P.G. 2001. Combretaceae. In: SINGH N.P., KARTHIKEYAN S. \& P. LAKSHMINARASIMHAN (eds.), Flora of Maharashtra State: Dicotyledons. Volume 2. Botanical Survey of India, Kolkata. p. 898.

EXELL A.W. 1954. Flora Malesiana. Volume 4. NoordhoffKolff N.V., Djakarta.

FOULKES T. 1861. Biographical Memoir of Dr. Rottler. Madras Journal of Literature and Science 22: 1-17.

GAMBLE J.S. 1919. Flora of the Presidency of Madras. Volume 1. Adlard \& Sons Limited, London.

GANGOPADHYAY M. \& T. CHAKRABARTY 1997. The family Combretaceae of Indian Subcontinent. Journal of Economic and Taxonomic Botany 2(2): 281-364.

GLORY A., JUDIN J., VASUDEVAN R. \& P. SUMATHI 2016. Preliminary phytochemical content and antibacterial activity of Ukshi (Calycopteris floribunda Lam.). Journal of Medicinal Plants Studies 4(2): 57-59.

IPNI 2020. International Plant Names Index. Published on the Internet http://www.ipni.org, The Royal Botanic Gardens, Kew, Harvard University Herbaria \& Libraries and Australian National Botanic Gardens. (Accessed on 05.06.2020).

POIRET J.L.M. 1811. Encyclopedie Methodique Botanique. Supplement 2. Chez H. Agasse, Imprimeur-Libraire, Paris.

LAMARCK J.-B. 1793. Tableau Encyclopedique et Methodique Botanique. Tome 1, Volume 2(2). Chez Panckoucke, Paris.

LAMARCK J.-B. 1819. Tableau Encyclopedique et Methodique Botanique. Tome 2, Volume 5(2). Chez Panckoucke, Paris. pp. $461 \& 485$.

MABBERLY D.J. 2008. Mabberley's Plant-Book. Third Edition. Cambridge University Press, Cambridge.

MABBERLY D.J. 2018. Mabberley's Plant-Book. Fourth Edition. Cambridge University Press, Cambridge.

MATTHEW K.M. 1993. Notes on an important botanical trip (1799-1800) of J.P. Rottler on the Coromandel Coast (India) with a translation of his original text, explanatory notes and a map. Botanical Journal of the Linnean Society 113: 351-388. https://doi.org/10.1111/ j.1095-8339.1993.tb00342.x

MURTHY G.V.S. \& V.J. NAIR 2018. The Flora of Kerala. Volume 2. Botanical Survey of India, Kolkata.

PAUL T.K., LAKSHMINARASIMHAN P., CHOWDHERY H.J., DASH S.S. \& P. SINGH 2015. Flora of West Bengal. Volume 2. Botanical Survey of India, Kolkata. 
PAVITHRA G.M., NAIK A.S., SIDDIQUA S., VINAYAKA K.S., PRASHITH KEKUDA T.R. \& S. MUKUNDA 2013. Antioxidant and Antimicrobial activity of flowers of Calycopteris floribunda (Roxb.) Poiret, Humboldtia brunonis Wall. and Kydia calycina Roxb.. International Journal of Drug Development and Research 5(2): 301-310.

PUNEKAR S.A. \& P. LAKSHMINARASIMHAN 2011. Flora of Anshi National Park Western Ghats-Karnataka. Biosphere, Pune.

ROXBURGH W. 1798. Plants of the Coast of Coromandel. Volume 1. W. Bulmer \& Co., London

SHARMA B.D., SINGH N.P., RAGHAVAN R.S. \& U.R. DESHPANDE 1984. Flora of Karnataka Analysis. Botanical Survey of India, Kolkata.

STAFLEU F.A. \& R.S. COWAN 1979. Taxonomic Literature. Volume 2. H-Le, W. Junk Publishers, Hague.

TALBOT W.A. 1911. Forest flora of the Bombay Presidency and Sind. Volume 2. Government at the Photozincographic Department, Poona.

TURLAND N.J., WIERSEMA J.H., BARRIE F.R., GREUTER W., HAWKSWORTHD.L., HERENDEEN P.S., KNAPP S., KUSBER W.-H., LI D.-Z., MARHOLD V, MAY T.W., MCNEILL J., MONRO A.M., PRADO J., PRICE M.J. \& G.F. SMITH (eds.) 2018. International Code of Nomenclature for algae, fungi, and plants (Shenzhen Code) adopted by the Nineteenth International Botanical Congress Shenzhen, China, July 2017. Regnum Vegetabile 159. Koeltz Botanical Books, Glashütten. https://doi.org/10.12705/Code.2018

VANTAMURI A.B., SOUNSHI Y.B., KOTRESH O. \& S.S. DODAMANI 2017. A preliminary study on total phenolic contents and antioxidant activities of Calycopteris floribunda root extracts. International Journal of Science and Research 52: 3020-3023. 